\title{
TCOM \\ How do we tackle the COVID-19 crisis? Mass media and psychological responses to the health crisis in Spain
}

\section{María Álvarez-Rementería Álvarez, Gorka Roman Etxebarrieta and María Dosil Santamaría}

\begin{abstract}
During global health crises, the mass media plays a key role in the construction of risk society. This paper analyses people's perception during the confinement in Spain regarding the role of mass media and its relationship with psychological responses and attitudes towards social control. Results from the survey $(n=704)$ suggest that certain groups have been more affected by the messages distributed by the media, rendering them more vulnerable to suffering from negative psychological responses. The mass media interferes with the manner in which people psychologically deal with this crisis and the behaviour that results from their perception of risk.
\end{abstract}

$\begin{array}{ll}\text { Keywords } & \text { Risk communication } \\ \text { DOI } & \text { https://doi.org/10.22323/2.20050205 }\end{array}$

Submitted: 22nd December 2020

Accepted: 30th June 2021

Published: 8th September 2021

Introduction

In December 2019, the outbreak of an unknown respiratory disease in Wuhan (Hubei province, China) raised worldwide attention [Wang et al., 2021]. With its strong capacity for transmission, the novel strain of the virus causing the COVID-19 disease has serious health consequences, particularly for the elderly or people with underlying pathologies. It rapidly spread throughout China and, on 30 January 2020, a global public health emergency was officially declared by the World Health Organization (WHO), urging affected countries to take measures to contain and slow the spread of the virus [Grasselli, Pesenti and Cecconi, 2020].

Local health authorities began to implement different containment measures, which has resulted in the use of a wide variety of strategies, depending on the context. In Europe, the rapid increase affected countries in a very unequal way, with Italy and, shortly after, Spain, suffering the worst-case scenarios [Yuan et al., 2020]. On March 15, the Spanish government declared a state of national emergency, ordering a 15-day total confinement of the population [Legido-Quigley et al., 2020], which was prolonged until the end of June 2020. Social distancing and 
mobility restrictions were generally put in place and accepted throughout the country. Consequently, and aside from the concerns about the disease itself, several studies have focused on the social repercussions of the pandemic within our society, particularly in terms of mental health [Ozamiz-Etxebarria et al., 2020], psychological effects [Pakpour and Griffiths, 2020] or social behaviour [Van Bavel et al., 2020], all considered to be key elements that have a severe impact on the manner in which people can emotionally and physiologically deal with this global crisis.

\section{Psychological responses during health emergencies}

Several studies have sought to investigate the psychological processes associated with infectious diseases, such as swine flu [Idoiaga Mondragón, 2015; Wheaton et al., 2012], influenza A [Bults et al., 2011], Ebola [Van Bortel et al., 2016] and, more recently, Covid-19 [Lee et al., 2020; Özdin and Bayrak Özdin, 2020; Pakpour and Griffiths, 2020; Roman Etxebarrieta et al., 2020; Wang et al., 2021], and how these processes affect the way in which people cope with these global emergencies [Idoiaga Mondragón, 2016; Van Bavel et al., 2020].

Historically, this type of global health crisis, particularly with regard to infectious diseases, has caused the highest death tolls. In this scenario, fear becomes one of the main emotional responses, which contributes to an increased perception of threat and, in turn, this causes people to experience negative psychological effects [Van Bavel et al., 2020]. In scenarios such as the one seen in Spain, with tight measures and long periods of confinement, it has been stressed that levels of stress, anxiety and depression during confinement have negatively interfered with the way people are coping with this global crisis [Ozamiz-Etxebarria et al., 2020]. In addition, if the fear turns out to be too excessive, it can cause harmful effects at the individual (phobia and anxiety) and social level (panic buying, among others) [Valero Cedeño et al., 2020]. Other authors note that fear may be caused by lack of information [Carleton, 2016].

Social responses in crisis situations are largely conditioned by the perception of a threat [Lunn et al., 2020; Pakpour and Griffiths, 2020]. Fear leads to the perception of a threat as being imminent and this affects people's behaviour [Van Bavel et al., 2020]. Consequently, it "transcends the individual and leads to the formation of collective cultures of fear" [Idoiaga, Gil de Montes and Valencia, 2016, p. 65]. According to Tomás-Sábado [2020], Covid-19 has been perceived as a real threat to life, activating all the existential fears of people. However, Engelhard et al. [2015] pointed out that fear can trigger safety behaviors such as hand washing to mitigate certain transmission threats but paradoxically can also increase fear and health anxiety. Based on this study, mass media communication plays a key role in the social construction of risk and, as she pointed out in a previous study [Idoiaga Mondragón, 2015], it leads to the creation of a common understanding of perceived risk among a globalized population known as a "risk society" [Beck, 1986].

Taking into account some recent studies regarding psychological responses during the Coronavirus crisis, there appears to be broad agreement amongst the literature that women present higher levels of anxiety and depression compared with men [Lee et al., 2020; Liu et al., 2020; Moghanibashi-Mansourieh, 2020;

Ozamiz-Etxebarria et al., 2020; Özdin and Bayrak Özdin, 2020; Valiente et al., 2020; 
Wang et al., 2021]. According to Wang et al. [2021], this might be related to their professional roles, very often linked to care, together with "the social role of the lead caregiver in the family" [p. 7], which increases the pressure of responsibility for others [Dosil Santamaría et al., 2021].

Alternatively, some discrepancies regarding the relationship between age and psychological responses have been found in the literature. According to Lee et al. [2020], who analysed the levels of fear and anxiety among workers in an American e-commerce company, younger adults reported higher scores regarding perceived fear and anxiety. Similar results were reported from a study carried out within the Iranian general population, which found higher levels of anxiety among the 21-40-year age group. Ozamiz-Etxebarria et al. [2020] also highlighted a progressive decrease in stress, anxiety and depression levels in relation to age, with the highest levels shown in the 18-25-year age group, followed by 26-60 years and, finally, those over 60. In line with Wang et al. [2021], this could be due to the fact that "with more experience, psychological self-regulation ability and psychological quality of the crowd will also increase" [p. 7]. Moreover, other studies have found that older adults had a greater predisposition towards suffering from mental illness, which could be related to the pressure of having family members - both children and elderly — under their care [Dosil Santamaría et al., 2021].

In short, both gender and age appear to be associated with the psychological responses observed when coping with this type of situation. Other aspects such as having a history of mental health problems [Cameron et al., 2020; Valiente et al., 2020], having a chronic disease [Dosil Santamaría et al., 2021; Ozamiz-Etxebarria et al., 2020], concern about the economic situation [Valiente et al., 2020] and a high exposure to corona-related news [Moghanibashi-Mansourieh, 2020] have also been identified as determining factors of anxiety.

\section{The role of mass media in a social emergency context}

The role played by mass media during social emergencies has been a recurring element of analysis within various academic disciplines for much of the 20th and 21st centuries. Experts have routinely turned to case studies that have been paradigmatic and highly representative in reference to the role played by media aimed at biasing people's behaviour and exercising social control among masses [Ashcroft, Griffiths and Tiffin, 2006]. Nonetheless, and despite the fact that media can exert influence and control over the society, it is important to underline that "reality" is socially constructed and, thus, media consumers can also be active actors in that shared construction of informational contexts. In the words of Couldry and van Dijck [2015] there are, indeed, continuous tensions between the social media and society, and therefore a struggle to create "reality" and to change it.

Tuchman [1976] points out the idea that "television entertainment is a highly political method of social control" [p. 51] which is charged with information about how the society should be structured and what the appropriate motives for behaviour should be. The media has the ability to decontextualize images, discourses and situations to reinsert them into alternative interpretive frameworks that respond to logics and struggles for hegemony [Juris, 2005]. In this line and 
according to Gitlin [1980], these hegemonic interests might manipulate certain images and situations, and reinsert them in new contexts where specific persons, movements, collectives and attitudes are shown as dangerous and subversive, thus, triggering fear so as to make themselves capable of exercising control over the masses. Nonetheless, Forgacs [1999] recognizes that press can also disclose the socioeconomic demands of the working classes and implement social and political awareness and activism.

This hegemony around the dissemination of information has become even more acute in recent decades [Aijmer, 2000]. The establishment and systematic reproduction of those value systems could also translate into the symbolic constitution of real or fictitious ideological adversaries and of political, social, or ethnocultural otherness [Bowman, 2001; Bowman, 2003; Yongtao, 2010].

Hegemonic media frameworks tend to question social protest and divergences that call into question the standardized social status quo, particularly when they question their basic assumptions about the market and the State, suggesting that these are run by dangerous and criminal individuals [Juris, 2005]. We should not ignore, in this sense, the fact that dualistic rhetoric is an effective mechanism for social control. Yongtao [2010] warns that the dualistic imagery that faces "evil" and the "civilized world" or us vs. them, does not leave room for a neutral thought or position. Any kind of dissent is therefore liable to be considered as an attack on that "we" and will therefore be socially stigmatized.

The media have a performative power [Austin, 1982; Bourdieu, 1991] capable of disfiguring the "reality" of certain contexts and groups, spreading information that would deepen fear and rejection of certain ideas and people. This fear could underlie much of the rhetoric of identity [Bowman, 2001; Bowman, 2003] and dualistic discourses [Yongtao, 2010], which could lead to effective social control by the authorities, government organizations, and police bodies and military.

Informal social control can also be exerted by individuals who are not officially legitimized to exercise such power. Following Groff [2015], "informal social control consists of the spectrum of actions taken by citizens to signal unacceptable behaviour" [p. 90]. These individuals try to regulate the socially deviant behaviours of others and sometimes even decide to take action against them.

Furthermore, social control has two dimensions: the internal-external and the direct-indirect dimensions. Internal social control occurs when an individual assumes the external rules set in society and complies with them. External social control happens where other individuals or groups observe individuals to make sure they comply with such rules. Direct-indirect dimension refers to the fact that some relationships are built precisely to execute social control, while others execute social control, even though they were not designed to do so. Social control may also vary depending on the size of the unit executing it, which ranges from families to blocks and neighbourhoods [Groff, 2015].

\section{Fake news and informational biases during the COVID-19 crisis}

Aside from the consequential challenges for health systems caused by the COVID-19 pandemic, misinformation, rumours and fake news have also created a 
significant struggle all around the globe due to their influence on people's understanding in regard to the origin, risks and other aspects of the disease. In this regard, Wheaton et al. [2012] warn that the widespread transmission of such information through mass media during pandemic crises might be correlated with high levels of anxiety and compensatory behaviour. Their results revealed that higher levels of anxiety coincided with the peak of the flu season, which also corresponded with an intense diffusion of related information through mass media communication [Wheaton et al., 2012]. Other authors pointed out how the media can generate psychological alterations related to the perception of threat to personal health [Sandín et al., 2020]. In addition, other studies highlighted the negative influence of media on anxiety, worry and sleep disorders [Gao et al., 2020; Roy et al., 2020]. In this context, fake news can negatively influence people's perception of current social and health-related scenarios.

The way fake news affects people's behaviour or attitudes, sometimes under the guise of a report whose content is frequently sensational [Pérez-Dasilva, Meso-Ayerdi and Mendiguren-Galdospín, 2020], has recently been the focus of research. For instance, evidence has emerged of racist attitudes towards the Chinese population following the COVID-19 outbreak [Shimizu, 2020]. According to this author, ineffective communication amplifies the risk of inappropriate behaviours such as xenophobia since "inaccurate and misleading headlines agitate members of the public, cause fear, impinge on public communication, and diminish countermeasures for the outbreak" [p. 685].

Amid this scenario, the term infodemic has emerged to refer to the "acute outpouring of information, including potentially misleading or inaccurate information" [World Health Organization, 2020b, para. 5] which, as they add, "makes it hard for people to find trustworthy sources and reliable guidance when they need it" [World Health Organization, 2020a, para. 1]. Infodemic in a health crisis situation such as the one being experienced currently, tends to generate fear and mistrust amongst citizens and, moreover, it might confuse people and prevent them from taking effective actions to stop the spread of the virus [Pérez-Dasilva, Meso-Ayerdi and Mendiguren-Galdospín, 2020]. According to these authors, the lack of clarity throughout the information provided by policymakers, heads of states and mass media has meant that they are also part of this misinformation.

All in all, as Pérez-Dasilva, Meso-Ayerdi and Mendiguren-Galdospín [2020] note, the COVID-19 crisis has become not only a health and economic crisis but also an informational crisis on a global scale.

In this context, the main objective of this study is to analyse people's perceptions about the role of media communication during the COVID-19 crisis and its association with perceived levels of anxiety and fear and people's attitudes towards social control measures.

For this purpose, the specific objectives are:

a) to compare the levels of perceived anxiety and fear according to gender and age regarding exposure to corona-related news and people's own economic, social and employment outlook; 
b) to compare people's perceptions (according to gender and age) towards the role played by media communication during the COVID-19 crisis, particularly with respect to its impact on psychological responses;

c) to analyse the statistically significant associations regarding attitudes in both exerting and replicating social control according to gender and age.

Methodology

\section{Participants}

This study included 704 participants from Spain, of whom $75.3 \%(n=530)$ were women and $24.7 \%(n=174)$ were men. In relation to age, $16.2 \%(n=114)$ were young people aged between 18 and 25 years, $42.9 \%(n=302)$ were aged between 26 and 39 years, $30.8 \%(n=217)$ were adults aged between 40 and 55 years and finally $10.1 \%(n=71)$ were older than 56 years $(M=37.9$; $\mathrm{SD}=14.9)$, the youngest participant being 18 years old and the oldest 74 years old. In addition, $20.5 \%$ $(n=144)$ indicated having a chronic disease and $79.5 \%(n=560)$ reported having no chronic disease. Moreover, $15.1 \%(n=106)$ indicated having had contact with COVID-19, while $84.9 \%(n=598)$ of the sample indicated not having had contact with people infected with COVID-19.

\section{Procedure}

The sampling was probability-based, so that all people had the opportunity to participate in the study, thus ensuring randomization. The questionnaire was sent out through social networks, and 950 individuals completed the questionnaire during the confinement period in Spain (from March 2020 to June 2020). After analysing the database in Microsoft Excel (https://products.office.com/), the questionnaire showed a pattern of more than $50 \%$ no-responses in several blocks. Consequently, we decided to exclude all questionnaires with less than $50 \%$ of the items completed, and thus 268 questionnaires were withdrawn from the sample, leaving a total of 704 participants. The study complied with all the provisions of Law 15/1999 on the Protection of Personal Data. In addition, participants were informed of the voluntary nature of participation and give their consent before starting to answer the questionnaire.

\section{Instrument}

Ad hoc questionnaire. This instrument gathers information on the participants in relation to gender, nationality, chronic illness status, and whether or not they have been in contact with COVID-19.

The research instrument was designed as a questionnaire in Spanish consisting of 24 items, divided into 3 thematic blocks. The first block was composed of 12 items, which described the sensations and feelings generated by the COVID-19 situation, with Likert-type responses ranging from 0 (never)-5 (always). For the descriptive analysis of the data, the answer 3 ("often") will be used. The second block was composed of seven items related to social norms, with dichotomous responses, using the affirmative answer. The last block of questions concerned the media and social alarm, for which 5 items were included with Likert-type responses from very much in disagreement (0) to very much in agreement (1). For the descriptive analysis, the chosen option for the analysis will be "often". 


\section{Data analysis}

The statistical program SPSS v.26 (SPSS, INC., Chicago, IL) was used for data analysis. Descriptive analyses of socio-demographic variables, chi-squares with the total of the item in each response and analysis of the effect size between the variables were calculated.

\section{Results}

\section{Sensations and feelings according to gender, age and chronic disease status}

Table 1 shows the questions that were answered in the affirmative using "bastante" [often]. Specifically, the answers of the item "hearing news about COVID-19 makes me anxious", showed statistically significant associations with gender, $\chi^{2}=17.60$, $p=.01, V_{\text {cramer }}=.16$, with a small effect size, with $9.7 \%(n=68)$ of the total sample being women who responded feeling quite anxious when hearing news about COVID-19 and 2.0\% $(n=14)$ being men. Likewise, "hearing news about COVID-19 scares me" also showed statistically significant associations with gender, $\chi^{2}=23.28, p=.01, V_{\text {cramer }}=.21$. The same applies to the following questions "being housebound makes me anxious" and "the fact that a family member is infected scares me" (see Table 1).

Table 1. Sensation and feeling according to gender.

\begin{tabular}{|lcccc|}
\hline & \multicolumn{2}{c}{$n(\%)$} & & \\
& women & men & $\chi^{2}$ & $V_{\text {cramer }}$ \\
\hline Hearing news about COVID-19 makes me & $9.7 \%$ & $2.0 \%$ & $17.60^{* *}$ & .16 \\
anxious. & $(n=68)$ & $(n=14)$ & & \\
Hearing news about COVID-19 scares me. & $8.7 \%$ & $1.3 \%$ & $23.28^{* * *}$ & .21 \\
& $(n=61)$ & $(n=7)$ & & \\
Being housebound makes me anxious. & $7.7 \%$ & $1.4 \%$ & $10.04^{*}$ & .11 \\
& $(n=54)$ & $(n=10)$ & & \\
The fact that a family member is infected & $18.8 \%$ & $6.5 \%$ & $21.37^{* * *}$ & .17 \\
scares me. & $(n=132)$ & $(n=46)$ & & \\
\hline
\end{tabular}

Note. ${ }^{* * *} p<.001 ;^{* *} p<.01 ;^{*} p<.05$.

Statistically significant associations were also found between responses to questions related to feelings and sensations during confinement and age. The highest frequencies and percentages were found in the 26-39-year age range (see Table 2).

Chronic disease status has only shown statistically significant associations in the question "Being housebound scares me" with an identical frequency and percentage, $\chi^{2}=12.89 p=.01, V_{\text {cramer }}=.12$ (see Table 3).

\section{Social norms according to gender, age and cohabitation}

Responding "yes" to the following question "I believe that by monitoring people who break the rules of confinement I am helping society", was significantly associated with gender, $\chi^{2}=12.18, p=.001, V_{\text {cramer }}=.13$ (see Table 4).

In Table 5, the items: "I tell my relatives, even by phone, to go out onto the street only when necessary", "I tell my neighbours to go outside only when necessary" and "I believe that by monitoring people who break the rules of confinement I am 
Table 2. Sensations and feelings according to age.

\begin{tabular}{|c|c|c|c|c|c|c|}
\hline \multicolumn{7}{|l|}{ Lockdown } \\
\hline & $18-25$ & $26-39$ & $40-55$ & $>56$ & $\chi^{2}$ & $V_{\text {cramer }}$ \\
\hline $\begin{array}{l}\text { Being housebound makes } \\
\text { me anxious }\end{array}$ & $\begin{array}{c}2.3 \% \\
(n=16)\end{array}$ & $\begin{array}{c}5.1 \% \\
(n=36)\end{array}$ & $\begin{array}{c}1.4 \% \\
(n=10)\end{array}$ & $\begin{array}{l}0.3 \% \\
(n=2)\end{array}$ & $49.50^{* * *}$ & .15 \\
\hline $\begin{array}{l}\text { Not knowing how long I } \\
\text { will have to be } \\
\text { housebound makes me } \\
\text { anxious. }\end{array}$ & $\begin{array}{c}4.4 \% \\
(n=31)\end{array}$ & $\begin{array}{c}8.1 \% \\
(n=57)\end{array}$ & $\begin{array}{c}3.1 \% \\
(n=22)\end{array}$ & $\begin{array}{c}0.7 \% \\
(n=5)\end{array}$ & $54.80^{* * *}$ & .16 \\
\hline $\begin{array}{l}\text { The fact that the } \\
\text { post-lockdown economy } \\
\text { will affect my wellbeing } \\
\text { after this crisis is over } \\
\text { causes me anxiety and fear. }\end{array}$ & $\begin{array}{c}5.3 \% \\
(n=37)\end{array}$ & $\begin{array}{c}9.4 \% \\
(n=66)\end{array}$ & $\begin{array}{c}5.3 \% \\
(n=37)\end{array}$ & $\begin{array}{c}2.7 \% \\
(n=29)\end{array}$ & $34.53^{* * *}$ & .13 \\
\hline $\begin{array}{l}\text { I think that after the } \\
\text { COVID- } 19 \text { crisis my work } \\
\text { situation will be } \\
\text { considerably different to } \\
\text { my situation before the } \\
\text { crisis. }\end{array}$ & $\begin{array}{c}3.4 \% \\
(n=24)\end{array}$ & $\begin{array}{c}6.8 \% \\
(n=48)\end{array}$ & $\begin{array}{c}3.6 \% \\
(n=25)\end{array}$ & $\begin{array}{c}1.4 \% \\
(n=10)\end{array}$ & $19.99^{*}$ & .10 \\
\hline $\begin{array}{l}\text { I think that after the } \\
\text { Coronavirus crisis, my } \\
\text { economic situation will be } \\
\text { very different to my } \\
\text { situation before the crisis. }\end{array}$ & $\begin{array}{c}4.1 \% \\
(n=29)\end{array}$ & $\begin{array}{c}4.8 \% \\
(n=34)\end{array}$ & $\begin{array}{c}4.4 \% \\
(n=31)\end{array}$ & $\begin{array}{c}1.3 \% \\
(n=9)\end{array}$ & $40.26^{* * *}$ & .14 \\
\hline
\end{tabular}

Note. ${ }^{* * *} p<.001 ;^{* *} p<.01 ;^{*} p<.05$.

Table 3. Sensation and feelings according to chronic illness status.

\begin{tabular}{|lcccc|}
\hline Lockdown & & & & \\
& yes & no & $\chi^{2}$ & $V_{\text {cramer }}$ \\
\hline Being housebound scares me. & $1.1 \%$ & $1.1 \%$ & $12.89^{* *}$ & .12 \\
& $(n=8)$ & $(n=8)$ & & \\
\hline
\end{tabular}

Note. ${ }^{* * *} p<.001 ;^{* *} p<.01{ }^{*} p<.05$.

Table 4. Social norms and gender.

\begin{tabular}{|llccc|}
\hline Social norms & \multicolumn{2}{c|}{$n(\%)$} & & \\
& women & men & $\chi^{2}$ & $V_{\text {cramer }}$ \\
\hline $\begin{array}{l}\text { I believe that by monitoring people who } \\
\text { break the rules of confinement I am helping } \\
\text { society. }\end{array}$ & $\begin{array}{c}13.9 \% \\
(n=98)\end{array}$ & $\begin{array}{c}7.7 \% \\
(n=54)\end{array}$ & $12.18^{* * *}$ & .13 \\
\hline
\end{tabular}

Note. ${ }^{* * *} p<.001 ;{ }^{* *} p<.01{ }^{*} p<.05$.

helping society" were significantly associated with age, but only for those in the middle age ranges, who gave these responses with a higher frequency and percentage than the rest of the ages (the youngest and the oldest).

\section{Mass media according to gender and age}

With regard to articles on the media in times of a pandemic, statistically significant associations were found according to gender and according to different age ranges (see Tables 6 and 7). 
Table 5. Social norms according to age.

\begin{tabular}{|c|c|c|c|c|c|c|}
\hline \multicolumn{7}{|l|}{ Social norms } \\
\hline & $18-25$ & $26-39$ & $40-55$ & $>56$ & $\chi^{2}$ & $V_{\text {cramer }}$ \\
\hline $\begin{array}{l}\text { I tell my relatives, even by } \\
\text { phone, to go out onto the } \\
\text { streets only when } \\
\text { necessary. }\end{array}$ & $\begin{array}{c}2.1 \% \\
(n=95)\end{array}$ & $\begin{array}{c}8 \% \\
(n=280)\end{array}$ & $\begin{array}{c}7.7 \% \\
(n=196)\end{array}$ & $\begin{array}{c}3.8 \% \\
(n=68)\end{array}$ & $11.06^{*}$ & .13 \\
\hline $\begin{array}{l}\text { I tell my neighbours to go } \\
\text { outside only when } \\
\text { necessary. }\end{array}$ & $\begin{array}{c}5.8 \% \\
(n=41)\end{array}$ & $\begin{array}{c}19 \% \\
(n=134)\end{array}$ & $\begin{array}{c}18.3 \% \\
(n=129)\end{array}$ & $\begin{array}{c}6.4 \% \\
(n=45)\end{array}$ & $25.59^{* * *}$ & .19 \\
\hline $\begin{array}{l}\text { I believe that by } \\
\text { monitoring people who } \\
\text { break the rules of } \\
\text { confinement I am helping } \\
\text { society. }\end{array}$ & $\begin{array}{c}2.1 \% \\
(n=15)\end{array}$ & $\begin{array}{c}8.0 \% \\
(n=56)\end{array}$ & $\begin{array}{c}7.7 \% \\
(n=54)\end{array}$ & $\begin{array}{c}3.8 \% \\
(n=27)\end{array}$ & $19.17^{* * *}$ & .17 \\
\hline
\end{tabular}

Table 6. Mass media according to gender.

\begin{tabular}{|lcccc|}
\hline Mass media & \multicolumn{2}{c}{$n(\%)$} & & \\
& women & men & $\chi^{2}$ & $V_{\text {cramer }}$ \\
\hline When I receive information from the media & $9.2 \%$ & $4.1 \%$ & $23.99^{* * *}$ & .19 \\
about Coronavirus, I feel anxious. & $(n=65)$ & $(n=29)$ & & \\
When I receive information from the media & $8.4 \%$ & $3.7 \%$ & $41.93^{* * *}$ & .24 \\
about Coronavirus, I feel scared. & $(n=59)$ & $(n=26)$ & & \\
\hline Note. ${ }^{* * *} p<.001$; $^{* *} p<.01{ }^{*} p<.05$. & & &
\end{tabular}

Table 7. Mass media according to age.

\begin{tabular}{|c|c|c|c|c|c|c|}
\hline \multicolumn{7}{|l|}{ Mass media } \\
\hline & $18-25$ & $26-39$ & $40-55$ & $>56$ & $\chi^{2}$ & $V_{\text {cramer }}$ \\
\hline $\begin{array}{l}\text { I think the media should } \\
\text { report more about other } \\
\text { news that is unrelated to } \\
\text { Coronavirus. }\end{array}$ & $\begin{array}{c}1.1 \% \\
(n=8)\end{array}$ & $\begin{array}{c}1.7 \% \\
(n=12)\end{array}$ & $\begin{array}{c}1.8 \% \\
(n=13)\end{array}$ & $\begin{array}{c}0.7 \% \\
(n=5)\end{array}$ & $38.85^{* *}$ & .14 \\
\hline $\begin{array}{l}\text { I believe that the excessive } \\
\text { media reporting about } \\
\text { Coronavirus is designed to } \\
\text { make society more } \\
\text { concerned than usual. }\end{array}$ & $\begin{array}{c}1.7 \% \\
(n=12)\end{array}$ & $\begin{array}{c}6.7 \% \\
(n=47)\end{array}$ & $\begin{array}{c}3.6 \% \\
(n=25)\end{array}$ & $\begin{array}{c}2.1 \% \\
(n=15)\end{array}$ & $30.75^{*}$ & .12 \\
\hline $\begin{array}{l}\text { I believe that the excessive } \\
\text { media reporting about } \\
\text { Coronavirus is designed to } \\
\text { make society feel scared }\end{array}$ & $\begin{array}{c}2.1 \% \\
(n=15)\end{array}$ & $\begin{array}{c}8.5 \% \\
(n=60)\end{array}$ & $\begin{array}{c}3.7 \% \\
(n=26)\end{array}$ & $\begin{array}{c}2.1 \% \\
(n=15)\end{array}$ & $39.20^{* *}$ & .14 \\
\hline
\end{tabular}

\section{Discussion}

\section{Perceived anxiety and fear, social norms and media according to gender}

The data collected in the present study indicate that women experience higher levels of anxiety and fear in comparison with men when watching, listening or reading news related to the COVID-19 crisis. In addition, when the participants were asked about the possibility of having a relative infected by COVID-19, once again, women reported higher levels of fear compared with men. As previously pointed out, the role of women as caregivers in the home could explain this 
vulnerable situation when compared with men, as this could increase the pressure of responsibility towards others [Dosil Santamaría et al., 2021]. Moreover, women might feel a heightened sense of fear of having a person close to them becoming infected, since they present a greater concern (compared with men) about transmitting the disease to the people with whom they live or care for [Ozamiz-Etxebarria et al., 2020].

The data also show that women have experienced higher levels of anxiety and fear during lockdown. In a recent COVID-19 fear and worry survey, it was women who showed a significantly greater impact than men [Sandín et al., 2020]. Likewise, the fact that women are usually more expose to shoulder the responsibility of cleaning and locking up could mean that they are forced to deal with a greater workload and, consequently, higher levels of stress [Fernández et al., 2016]. In this sense, it should be noted that the NIS (National Institute of Statistics), when reporting on the care of dependants, found that $8.6 \%$ of women (compared with $5.1 \%$ of men) are responsible for these tasks [Instituto Nacional de Estadística, 2020]. In a similar vein, a report published on single-parent families indicated that the number of single-parent families headed by women is more than four times higher than those headed by men [Instituto Nacional de Estadística, 2019]. According to recent studies [McLaren et al., 2020; Wenham, Smith and Morgan, 2020], in exceptional situations - such as the current pandemic - this gender imbalance in the division of labour has disproportionately increased. These consequences can be linked to a social structure that places those who are responsible for care (mostly women) at a greater risk of being infected with COVID-19, thus making these individuals more vulnerable to suffering from negative psychological responses.

This condition affects not only those in the private sphere but also in the public since women are more frequently employed to undertake jobs and tasks related to caregiving [Martín Palomo, 2008; Llusia, 2007], which could translate into a significantly more stressful situation in terms of workload, particularly in a context of extreme distress such as the one generated by the COVID-19 crisis. It is well-documented in the literature that this situation could underpin the higher levels of anxiety and fear shown by women [Lee et al., 2020; Liu et al., 2020; Moghanibashi-Mansourieh, 2020; Ozamiz-Etxebarria et al., 2020; Özdin and Bayrak Özdin, 2020; Valiente et al., 2020; Wang et al., 2021].

Our data also revealed that women were more willing than men to exercise control over other people if this was of benefit for the whole society. In particular, many of the female participants indicated that they think they are helping the community by exerting social control over other people that do not comply with the rules that have been put in place to tackle the pandemic. This phenomenon could also be related to the fact that women usually adopt the role of caretakers as a consequence of social and cultural pressure [Galarza Fernández, Cobo Bedía and Esquembre Cerdá, 2016; Llusia, 2007]. Further research is needed to confirm whether these factors underlie the higher levels of anxiety and fear that women appear to have experienced during the COVID-19 crisis.

For all these reasons, we could say that there is a gendered pattern in how people psychologically and emotionally deal the COVID-19 crisis. As it stated the literature, certain individuals and groups can be victims of particular situations where structural [Estrada-Tanck, 2017] and symbolic violence [Bardall, 2020; 
Galarza Fernández, Cobo Bedía and Esquembre Cerdá, 2016] occur. Women are more frequently victims of this kind of violence and often have to face situations of stigma within their own society in terms of the tasks they are expected to carry out (caregivers and housekeepers) and the social roles they are supposed to assume and perform [Fernández et al., 2014]. The aforementioned scenarios could create the existence of endemic structural violence [Galtung, 2005] that particularly affects women, but also one of symbolic violence that is frequently created and distributed by mass media, leading to the legitimation of that situation of inequity [Bourdieu, 1991; Juris, 2005; Galarza Fernández, Cobo Bedía and Esquembre Cerdá, 2016].

\section{Perceived anxiety and fear, social norms and media according to age}

When the participants were asked about their feelings about being confined at home and not knowing when the confinement would end, those in the 26-39-year age range reported anxiety more often than the other groups. This could be related to the fact that middle aged people tend to assign special importance to their outside social life [Cuenca Cabeza, 2002; Roberts, 2012; San Salvador del Valle, 2002].

The two central age-ranges (26-39/40-55 years) experienced anxiety and fear more often than the youngest and the oldest when they were asked about their wellbeing and their future economic and work situation. According to the literature, these two central age ranges are those with higher domestic and economic responsibilities within their own families [Fernández Cordón and Tobío Soler, 2005], and therefore reconciling their family duties with work and creating a work-life balance are key factors for their emotional well-being.

Regarding the role of the mass media when reporting on the COVID-19 pandemic, participants in the two central age ranges (26-39/40-55 years) were the ones who experienced fear more often when listening to corona-related news. These two age ranges were also the ones that most frequently expressed the view that the media should report more about other (non-pandemic) news and also that the excessive media reporting about Coronavirus is designed to make society feel fear and unnecessary levels of concern about the COVID-19 crisis. In this regard, a quantitative study carried out in Mexico by Ramos Lira, Saltijeral and Saldívar [1995] revealed that middle age people more frequently consume distressing news reported by the mass media and that this consumption has a profound impact on the development of feelings related to anxiety and fear.

In previous sections we mentioned that the media is capable of presenting the information in adapted ways, and "reality" could be artificially constructed in certain contexts. Sometimes this occurs in such a way that it spreads information that deepens fear in certain situations of extreme social distress [Juris, 2005] such as the one caused by the COVID-19 pandemic. We should not forget that in the words of Hall [1997] the media are in charge of shaping the way in which this information is transmitted. Mass media communication thus plays a relevant role in the social construction of risk [Idoiaga, Gil de Montes and Valencia, 2016], which leads to the creation of a shared imaginary [Bowman, 2003] of perceived risk among the population, known as a "risk society" [Beck, 1986]. 
Furthermore, the data also showed that the two central age ranges were more willing to exercise control over other people if this was beneficial for the whole society. In this regard, the two central age ranges more frequently indicated the belief that they are helping the community by exerting social control over the rest of the people if they are not obeying the norms and rules applied to tackle the pandemic. As mentioned previously, it is people in these age ranges who have greater domestic and economic responsibilities within their own families [Fernández Cordón and Tobío Soler, 2005], which may be related to a higher exercise of control over others for a shared benefit.

In sum, social responses in health crisis situations are profoundly shaped by the perception of threat, in which the media play a decisive role [Lunn et al., 2020; Pakpour and Griffiths, 2020]. Fear becomes, in this sense, one of the main emotional responses observed during this kind of crisis and it usually leads to the perception of a threat as imminent and, therefore, it will affect people's behaviour [Van Bavel et al., 2020].

\section{Feelings about being housebound according to having (or not) a chronic disease}

In accordance with the literature [Dosil Santamaría et al., 2021; Ozamiz-Etxebarria et al., 2020], the results suggest that having a chronic disease appears to facilitate the appearance of negative psychological responses. When the participants were asked if they felt scared by the fact of being housebound, those who reported having a chronic disease answered more positively than those who do not suffer from a chronic disease. In line with Dosil Santamaría et al. [2021], people with chronic diseases might show more severe symptoms if they become infected with COVID-19 in comparison with non-chronically ill individuals. Thus, people with a chronic illness are more vulnerable to negative psychological effects such as stress, anxiety or depression. Furthermore, Ozamiz-Etxebarria et al. [2020] warn that cohabitating with people that suffer from a chronic disease during lockdown is also a facilitator of anxiety, stress or insomnia. This suggests that there should be further research on the difficulties that both people with chronic diseases and their partners face during a health crisis in order to provide them with the support needed to navigate this vulnerable situation.

\section{Conclusions}

According to the literature, social responses in crisis situations are largely shaped by the perception of threat [Lunn et al., 2020; Pakpour and Griffiths, 2020]. Fear leads to the perception of a threat as imminent and thus affects people's behaviour [Van Bavel et al., 2020]. In this scenario, mass media communication plays a key role in the social construction of risk [Idoiaga Mondragón, 2015], which leads to a common understanding of perceived risk among a globalized population known as a "risk society" [Beck, 1986]. In this respect, fake news and misinformation can negatively influence people's perception of the current situation. The extensive transmission of this misleading and inaccurate information through mass media during the pandemic has led to the emergent risky phenomenon that World Health Organization [World Health Organization, 2020a] has named infodemic. Following World Health Organization [2020b], this crisis is due to the overabundance of information (online and offline) that can include intentional attempts to distribute fake information. Disinformation in times of COVID-19 has already brought 
consequences in different scenarios: the polarization of public debates, amplification of hate speech, intensification of violence and human rights violations, amongst others [World Health Organization, 2020a; World Health Organization, 2020b].

How infodemic has influenced people's perception of threat has been the subject of study in this article. It has been found that certain groups or collectives have been notably more affected by the influence of the messages distributed by the media. On the basis of the data collected from the participants surveyed in Spain during the recent COVID-19 confinement, we can state that there is a gendered pattern with regard to how people are psychologically and emotionally dealing with the COVID-19 crisis, with women reporting more anxiety and fear about their health, economic and social situation as a result of the crisis, particularly when watching, listening or reading news related to COVID-19. Moreover, in comparison with men, women have more frequently reported their willingness to exercise informal and indirect control [Groff, 2015]. In our view, the role of caregiver that is often fulfilled by women (both in the public and the private sphere) could contribute towards explaining these findings.

In addition, our data indicate that people in the middle-age groups also show a greater tendency to suffer from negative psychological responses and perform informal control. Family and economic responsibilities, together with the challenge of creating a work-life balance, could underlie these results. Participants in these two age ranges displayed the most negativity regarding the role played by the mass media, particularly in terms of the quantity of COVID-19-related news along with the way in which the news was released with the purpose of creating fear among viewers, listeners and readers. This phenomenon could be related to the fact that the mass media tend to create informational contexts of shared hazards that eventually contribute towards a "risk society" [Beck, 1986].

Taken together, the findings of this study pave the way for future research on how mass media affects people's perception of threat and the way people psychologically and emotionally deal with this current health crisis. Thus, the infodemic appears to represent an emergent risk related to global communication while the role played by mass media interferes with the manner people perceive risk, and, ultimately, how they behave. 
Aijmer, G. (2000). 'Introduction: the idiom of violence in imaginary and discourse'. In: Meanings of violence: a cross cultural perspective. Ed. by G. Aijmer and J. Abbink. Oxford, U.K.: Berg Publishers.

Ashcroft, B., Griffiths, G. and Tiffin, H., eds. (2006). The postcolonial studies reader. Oxford, U.K.: Routledge.

Austin, J. L. (1982). Cómo hacer cosas con palabras: palabras y acciones. Barcelona, Spain: Paidós.

Bardall, G. (2020). 'Symbolic violence as a form of violence against women in politics: a critical examination'. Revista Mexicana de Ciencias Políticas y Sociales 65 (238), pp. 379-389. https://doi.org/10.22201/fcpys.2448492xe.2020.238.68152.

Beck, U. (1986). Risikogesellschaft: auf dem Weg in eine andere Moderne. Frankfurt, Germany: Suhrkamp.

Bourdieu, P. (1991). Language and symbolic power. Cambridge, MA, U.S.A.: Harvard University Press.

Bowman, G. (2001). 'The violence in identity'. In: Anthropology of violence and conflict. Ed. by B. E. Schmidt and I. W. Schröder. London, U.K.: Routledge, pp. 25-46.

- (2003). 'Constitutive violence and the nationalist imaginary. Antagonism and defensive solidarity in 'Palestine' and 'former Yugoslavia'. Social Anthropology 11 (3), pp. 319-340. https://doi .org/10.1111/j.1469-8676.2003.tb00081.x.

Bults, M., Beaujean, D. J. M. A., de Zwart, O., Kok, G., van Empelen, P., van Steenbergen, J. E., Richardus, J. H. and Voeten, H. A. C. M. (2011). 'Perceived risk, anxiety, and behavioural responses of the general public during the early phase of the Influenza A (H1N1) pandemic in the Netherlands: results of three consecutive online surveys'. BMC Public Health 11, 2. https://doi.org/10.1186/1471-2458-11-2.

Cameron, E. E., Joyce, K. M., Delaquis, C. P., Reynolds, K., Protudjer, J. L. P. and Roos, L. E. (2020). 'Maternal psychological distress \& mental health service use during the COVID-19 pandemic'. Journal of Affective Disorders 276, pp. 765-774. https://doi.org/10.1016/j.jad.2020.07.081.

Carleton, R. N. (2016). 'Fear of the unknown: one fear to rule them all?' Journal of Anxiety Disorders 41, pp. 5-21. https://doi.org/10.1016/j.janxdis.2016.03.011.

Couldry, N. and van Dijck, J. (2015). 'Researching social media as if the social mattered'. Social Media + Society 1 (2). https://doi.org/10.1177/2056305115604174.

Cuenca Cabeza, M. (2002). 'El ocio de los jóvenes, un enigma formativo sin resolver'. Adoz: Revista de Estudios de Ocio 22, pp. 20-23.

Dosil Santamaría, M., Ozamiz-Etxebarria, N., Redondo Rodríguez, I., Jaureguizar Alboniga-Mayor, J. and Picaza Gorrotxategi, M. (2021). 'Impacto psicológico de la COVID-19 en una muestra de profesionales sanitarios españoles'. Revista de Psiquiatría y Salud Mental 14 (2), pp. 106-112. https://doi.org/10.1016/j.rpsm.2020.05.004.

Engelhard, I. M., van Uijen, S. L., van Seters, N. and Velu, N. (2015). 'The effects of safety behavior directed towards a safety cue on perceptions of threat'. Behavior Therapy 46 (5), pp. 604-610. https : //doi . org/10.1016/j . beth. 2014.12.006.

Estrada-Tanck, D. (2017). ‘Violencia de género y vulnerabilidad: estrategias locales para reclamar los derechos de la mujer en México'. Ciencia Jurídica 6 (11), pp. 7-27. https://doi.org/10.15174/cj.v6i1.221. 
Fernández, J., Quiroga, M. Á., Escorial, S. and Privado, J. (2014). ‘Explicit and implicit assessment of gender roles'. Psicothema 26 (2), pp. 244-251. https://doi.org/10.7334/psicothema2013.219.

- (2016). 'The gendered division of housework'. Psicothema 28 (2), pp. 130-136. https://doi.org/10.7334/psicothema2015.169.

Fernández Cordón, J. A. and Tobío Soler, C. (2005). Conciliar las responsabilidades familiares y laborales: políticas y prácticas sociales. Madrid, Spain: Fundación Alternativas.

Forgacs, D. (1999). The Antonio Gramsci reader. Selected writings 1916-1935. London, U.K.: Lawrence \& Wishart.

Galarza Fernández, E., Cobo Bedía, R. and Esquembre Cerdá, M. (2016). ‘Medios y violencia simbólica contra las mujeres'. Revista Latina de Comunicación Social 71, pp. 818-832. https://doi .org/10.4185/RLCS-2016-1122.

Galtung, J. (2005). Pax Pacifica: terrorism, the Pacific hemisphere, globalisation and peace studies. London, U.K.: Pluto Press.

Gao, J., Zheng, P., Jia, Y., Chen, H., Mao, Y., Chen, S., Wang, Y., Fu, H. and Dai, J. (2020). 'Mental health problems and social media exposure during COVID-19 outbreak'. PLoS ONE 15 (4), e0231924. https://doi.org/10.1371/journal . pone.0231924.

Gitlin, T. (1980). The whole world is watching: mass media in the making and unmaking of the new left. Berkeley, CA, U.S.A.: University of California Press.

Grasselli, G., Pesenti, A. and Cecconi, M. (2020). 'Critical care utilization for the COVID-19 outbreak in Lombardy, Italy. Early experience and forecast during an emergency response'. JAMA 323 (16), pp. 1545-1546. https://doi.org/10.1001/jama.2020.4031.

Groff, E. R. (2015). 'Informal social control and crime events'. Journal of Contemporary Criminal Justice 31 (1), pp. 90-106. https://doi.org/10.1177/1043986214552619.

Hall, S. (1997). 'The local and the global: globalization and ethnicity'. In: Dangerous liaisons: gender, nation, and postcolonial perspectives. Ed. by A. McClintock, A. Mufti and E. Shohat. Minneapolis, MN, U.S.A.: University of Minnesota Press.

Idoiaga, N., Gil de Montes, L. and Valencia, J.-F. (2016). 'Communication and representation of risk in health crises: the influence of framing and group identity / Comunicación en crisis sanitarias y representación del riesgo. La influencia del framing y la identidad grupal'. International Journal of Social Psychology / Revista de Psicología Social 31 (1), pp. 59-74. https://doi.org/10.1080/02134748.2015.1101313.

Idoiaga Mondragón, N. (2015). ‘El papel de los medios online en epidemias sanitarias: una comparación de las esferas públicas de México y España / The analysis of the online newspapers in health epidemics: a comparison between the public sphere of Mexico and Spain'. Medica Review. Revista Internacional de Humanidades Médicas 4 (1), pp. 17-29. https://doi.org/10.37467/gka-revmedica.v4.855.

- (2016). 'Ebola eguneroko pentsamenduan barneratzen: gizarte-irudikapena, arrisku-hautematea eta emozioak'. Uztaro: Giza eta Gizarte-Zientzien Aldizkaria (96), pp. 49-64.

Instituto Nacional de Estadística (2019). Encuesta de Población Activa (EPA). Módulo sobre conciliación entre la vida laboral y la familiar. Año 2018. Notas de prensa. URL: https://www.ine.es/prensa/epa_2018_m.pdf. 
Instituto Nacional de Estadística (2020). Encuesta Continua de Hogares (ECH). Datos referidos al valor medio del periodo. Número de hogares monoparentales según sexo, edad y estado civil del progenitor. URL: https://www. ine. es/jaxi/Datos.htm?pat h=/t20/p274/serie/prov/p01/\&file=01017.px\#! tabs-tabla.

Juris, J. S. (2005). 'Violencia representada e imaginada. Jóvenes activistas, el Black Bloc y los medios de comunicación en Génova'. In: Jóvenes sin tregua: culturas y políticas de la violencia. Ed. by F. J. Ferrándiz Martín and C. Feixa Pámpols. Barcelona, Spain: Anthropos Editorial, pp. 185-208.

Lee, S. A., Mathis, A. A., Jobe, M. C. and Pappalardo, E. A. (2020). 'Clinically significant fear and anxiety of COVID-19: a psychometric examination of the Coronavirus Anxiety Scale'. Psychiatry Research 290, 113112. https://doi.org/10.1016/j.psychres.2020.113112.

Legido-Quigley, H., Mateos-García, J. T., Regulez Campos, V., Gea-Sánchez, M., Muntaner, C. and McKee, M. (2020). 'The resilience of the Spanish health system against the COVID-19 pandemic'. The Lancet Public Health 5 (5), E251-E252. https://doi.org/10.1016/s2468-2667(20)30060-8.

Liu, N., Zhang, F., Wei, C., Jia, Y., Shang, Z., Sun, L., Wu, L., Sun, Z., Zhou, Y., Wang, Y. and Liu, W. (2020). 'Prevalence and predictors of PTSS during COVID-19 outbreak in China hardest-hit areas: gender differences matter'. Psychiatry Research 287, 112921.

https://doi.org/10.1016/j.psychres.2020.112921.

Llusia, M. (2007). 'Mujeres, cuidados y dependencia'. Página Abierta 182, pp. 22-23.

Lunn, P. D., Belton, C. A., Lavin, C., McGowan, F. P., Timmons, S. and Robertson, D. A. (2020). 'Using behavioral science to help fight the Coronavirus: a rapid, narrative review'. Journal of Behavioral Public Administration 3 (1), pp. 1-15. https://doi.org/10.30636/jbpa.31.147.

Martín Palomo, M. T. (2008). 'Los cuidados y las mujeres en las familias'. Política y Sociedad 45 (2), pp. 29-47.

McLaren, H. J., Wong, K. R., Nguyen, K. N. and Mahamadachchi, K. N. D. (2020). 'Covid-19 and women's triple burden: vignettes from Sri Lanka, Malaysia, Vietnam and Australia'. Social Sciences 9 (5), 87. https://doi.org/10.3390/socsci9050087.

Moghanibashi-Mansourieh, A. (2020). 'Assessing the anxiety level of Iranian general population during COVID-19 outbreak'. Asian Journal of Psychiatry 51, 102076. https://doi.org/10.1016/j.ajp.2020.102076.

Ozamiz-Etxebarria, N., Dosil-Santamaria, M., Picaza-Gorrochategui, M. and Idoiaga-Mondragon, N. (2020). 'Niveles de estrés, ansiedad y depresión en la primera fase del brote del COVID-19 en una muestra recogida en el norte de España / Stress, anxiety, and depression levels in the initial stage of the COVID-19 outbreak in a population sample in the northern Spain'. Cadernos de Saúde Pública 36 (4). https : //doi . org/10.1590/0102-311x00054020.

Özdin, S. and Bayrak Özdin, Ş. (2020). 'Levels and predictors of anxiety, depression and health anxiety during COVID-19 pandemic in Turkish society: the importance of gender'. International Journal of Social Psychiatry 66 (5), pp. 504-511. https://doi.org/10.1177/0020764020927051.

Pakpour, A. H. and Griffiths, M. D. (2020). 'The fear of COVID-19 and its role in preventive behaviors'. Journal of Concurrent Disorders 2 (1), pp. 58-63.

URL: https://concurrentdisorders.ca/2020/04/03/the-fear-of-covid-19and-its-role-in-preventive-behaviors/. 
Pérez-Dasilva, J.-A., Meso-Ayerdi, K. and Mendiguren-Galdospín, T. (2020). ‘Fake news y coronavirus: detección de los principales actores y tendencias a través del análisis de las conversaciones en Twitter'. El Profesional de la Información 29 (3), e290308. https://doi.org/10.3145/epi . 2020.may.08.

Ramos Lira, L., Saltijeral, M. T. and Saldívar, G. (1995). 'El miedo a la victimización y su relación con los medios masivos de comunicación'. Salud Mental 18 (2), pp. 35-43. URL: http://www.revistasaludmental.mx/index.php/salud_menta l/article/view/559/559.

Roberts, K. (2012). 'The leisure of young people in contemporary society / El ocio de los jóvenes en la sociedad contemporánea'. Arbor: Ciencia, Pensamiento y Cultura 188 (754), pp. 327-337. https://doi.org/10.3989/arbor.2012.754n2006.

Roman Etxebarrieta, G., Álvarez-Rementería Álvarez, M., Pérez-Izaguirre, E. and Dosil Santamaria, M. (2020). ‘El papel de los medios de comunicación en situaciones de crisis sanitaria. La percepción de la población en torno al control y las normas sociales durante la pandemia del COVID-19 / The role of media in health crisis scenarios. The perception of society on social control and norms during the COVID-19 pandemic'. Revista Latina de Comunicación Social 78, pp. 437-456. https://doi .org/10.4185/RLCS-2020-1484.

Roy, D., Tripathy, S., Kumar Kar, S., Sharma, N., Kumar Verma, S. and Kaushal, V. (2020). 'Study of knowledge, attitude, anxiety \& perceived mental healthcare need in Indian population during COVID-19 pandemic'. Asian Journal of Psychiatry 51,102083. https://doi.org/10.1016/j.ajp.2020.102083.

San Salvador del Valle, R. (2002). 'El valor del ocio en los jóvenes'. Adoz: Revista de Estudios de Ocio 22, pp. 5-13.

Sandín, B., Valiente, R. M., García-Escalera, J. and Chorot, P. (2020). 'Impacto psicológico de la pandemia de COVID-19: efectos negativos y positivos en población española asociados al periodo de confinamiento nacional'. Revista de Psicopatología y Psicología Clínica 25 (1), pp. 1-22. https://doi.org/10.5944/rppc. 27569.

Shimizu, K. (2020). '2019-nCoV, fake news, and racism'. The Lancet 395 (10225), pp. 685-686. https://doi.org/10.1016/s0140-6736(20)30357-3.

Tomás-Sábado, J. (2020). 'Miedo y ansiedad ante la muerte en el contexto de la pandemia de la COVID-19'. Revista de Enfermería y Salud Mental (16), pp. 26-30.

Tuchman, G. (1976). 'Mass media values'. Society 14 (1), pp. 51-54. https://doi.org/10.1007/bf02694650.

Valero Cedeño, N. J., Vélez Cuenca, M. F., Duran Mojica, Á. A. and Torres Portillo, M. (2020). 'Afrontamiento del COVID-19: estrés, miedo, ansiedad y depresión'. Enfermería Investiga 5 (3), pp. 63-70. URL: https ://revistas .uta.ed u.ec/erevista/index.php/enfi/article/view/913.

Valiente, C., Vázquez, C., Peinado, V., Contreras, A. and Trucharte, A. (2020). Estudio nacional representativo de las respuestas de los ciudadanos de España ante la crisis de Covid-19: respuestas psicológicas. Resultados preliminares. Informe técnico 2.0. Síntomas de ansiedad, depresión y estrés postraumático ante el COVID-19: prevalencia y predictores. Universidad Complutense de Madrid. URL: https://www.ucm.es/inventap/file/vida-covid19--informe-ejecutiv omalestar3520-final-1. 
Van Bavel, J. J., Baicker, K., Boggio, P. S., Capraro, V., Cichocka, A., Cikara, M., Crockett, M. J., Crum, A. J., Douglas, K. M., Druckman, J. N., Drury, J., Dube, O., Ellemers, N., Finkel, E. J., Fowler, J. H., Gelfand, M., Han, S., Haslam, S. A., Jetten, J., Kitayama, S., Mobbs, D., Napper, L. E., Packer, D. J., Pennycook, G., Peters, E., Petty, R. E., Rand, D. G., Reicher, S. D., Schnall, S., Shariff, A., Skitka, L. J., Smith, S. S., Sunstein, C. R., Tabri, N., Tucker, J. A., van der Linden, S., van Lange, P., Weeden, K. A., Wohl, M. J. A., Zaki, J., Zion, S. R. and Willer, R. (2020). 'Using social and behavioural science to support COVID-19 pandemic response'. Nature Human Behaviour 4 (5), pp. 460-471. https://doi .org/10.1038/s41562-020-0884-z.

Van Bortel, T., Basnayake, A., Wurie, F., Jambai, M., Koroma, A. S., Muana, A. T., Hann, K., Eaton, J., Martin, S. and Nellums, L. B. (2016). 'Psychosocial effects of an Ebola outbreak at individual, community and international levels'. Bulletin of the World Health Organization 94 (3), pp. 210-214. https://doi.org/10.2471/BLT.15.158543.

Wang, Y., Di, Y., Ye, J. and Wei, W. (2021). 'Study on the public psychological states and its related factors during the outbreak of coronavirus disease 2019 (COVID-19) in some regions of China'. Psychology, Health $\mathcal{E}$ Medicine 26 (1), pp. 13-22. https://doi.org/10.1080/13548506.2020.1746817.

Wenham, C., Smith, J. and Morgan, R. (2020). 'COVID-19: the gendered impacts of the outbreak'. The Lancet 395 (10227), pp. 846-848. https://doi.org/10.1016/s0140-6736(20)30526-2.

Wheaton, M. G., Abramowitz, J. S., Berman, N. C., Fabricant, L. E. and Olatunji, B. O. (2012). 'Psychological predictors of anxiety in response to the H1N1 (swine flu) pandemic'. Cognitive Therapy and Research 36 (3), pp. 210-218. https://doi.org/10.1007/s10608-011-9353-3.

World Health Organization (2020a). 1st WHO Infodemiology Conference. How infodemics affect the world \& how they can be managed. Geneva, Switzerland, 30th June-16th July 2020. URL: https : / /www . who. int/news-room/events/deta il/2020/06/30/default-calendar/1st-who-infodemiology-conference.

- (18th August 2020b). 'Joint call for papers - Special issues on Infodemiology'. URL: https://www . who. int/news-room/articles-detail/joint-call-for-pa pers-special-issues-on-infodemiology.

Yongtao, L. (2010). 'Discourse, meanings and IR studies: taking the rhetoric of "Axis of Evil" as a case'. CONfines de Relaciones Internacionales y Ciencia Politica 6 (11), pp. 85-107.

Yuan, J., Li, M., Lv, G. and Lu, Z. K. (2020). 'Monitoring transmissibility and mortality of COVID-19 in Europe'. International Journal of Infectious Diseases 95, pp.311-315. https://doi.org/10.1016/j.ijid.2020.03.050.

Authors

Álvarez-Rementería Álvarez, María

Ph.D. student in the Psychodidactic program (UPV/EHU, 2016-present), Master's Degree in Psychodidactics: Educational Psychology and Specific Didactics (UPV /EHU, 2015-2016) and graduated in Primary Education Teaching (UCM, 2011-2015). Her main activity is focused on her doctoral thesis, which revolves around the on-going training of Primary Education teachers in order to develop more inclusive educational practices. For this purpose, the Basque Government has granted a Pre-doctoral contract (2019-present) for the development of the project in the Department of Didactics and School Organization of the UPV/EHU, under the direction of two of the members and collaborators of KideOn: Leire Darretxe and 
Maite Arandia. At the beginning of 2019, she enjoyed a stay at NUI — Galway (Ireland). In addition, in 2019 she received dual training in the field of Children's Rights and, especially, about the situation of minor migrants without family references in Spain. She has participated in different International Congresses and her recent incorporation to the KideOn research team is allowing her to join new projects, that are in the application process, in the field of educational and social inclusion. E-mail: maria.alvarezrementeria@ehu.eus.

Roman Etxebarrieta, Gorka

Gorka Roman Etxebarrieta holds a Ph.D. in Political Science from the University of the Basque Country (UPV /EHU) and he is currently finishing his second Ph.D. in Psychodidactics. He is professor at the Department of Language and Literature Teaching in the Faculty of Education of this same university. He has several Bachelor's Degrees in Basque Philology, English Philology, and Social and Cultural Anthropology. He has done various research stays; at Kent University (The United Kingdom), at the University of Bayonne (France), at the University Institute of Lisbon (Portugal), and at Columbia University (New York). His expertise includes discourse analysis, the construction of political and linguistic identity, and social-educative inclusion processes. He is member of several research groups and international research projects. He is also the Principal Investigator in three different international Erasmus+ projects. He is head editor of various books on educational innovation and social-educative inclusion. He is also the director of two international congresses on social and educational inclusion. He has multiple impact publications in topics such as social and educational inclusion and COVID-19. E-mail: gorka.roman@ehu.eus.

Dosil Santamaría, María

María Dosil is a Doctor in Educational Psychology and Specific Didactics. She is a professor in the Department of Educational Sciences in the area of knowledge of research methods in the Faculty of Education of Bilbao (UPV/EHU). She is a family mediator and social educator. Her lines of research have revolved around violence and victimization in dating relationships, specifically those of minors under the guardianship of the different Provincial Councils. In addition, she has 6 years of work experience in centers for behavioral problems with adolescents in conflict with the law. Recently, he has published a dozen articles on Covid-19 in Q1 magazines. She has also disseminated results at national and international congresses (more than 15 contributions), coordinated symposia, and has a long research stay in Brazil. E-mail: maria.dosil@ehu.eus.

\section{How to cite}

Álvarez-Rementería Álvarez, M., Roman Etxebarrieta, G. and Dosil Santamaría, M. (2021). 'How do we tackle the COVID-19 crisis? Mass media and psychological responses to the health crisis in Spain'. JCOM 20 (05), A05.

https://doi.org/10.22323/2.20050205. 